\title{
Effect of Mg doping and sintering temperature on structural and morphological properties of samarium-doped ceria for IT-SOFC electrolyte
}

\author{
Syed Ismail Ahmad ${ }^{1}$ (D) Tasneem Mohammed $^{2} \cdot$ Amal Bahafi $^{2} \cdot$ \\ Madireddy Buchi Suresh ${ }^{3}$
}

Received: 8 March 2017/Accepted: 17 April 2017/Published online: 21 April 2017

(c) The Author(s) 2017. This article is an open access publication

\begin{abstract}
Samples of $\mathrm{Sm}$ and $\mathrm{Mg}$ co-doped ceria electrolyte of $\mathrm{Ce}_{1-x} \mathrm{Sm}_{x-y} \mathrm{Mg}_{y} \mathrm{O}_{2-\delta}(x=0.2 ; y=0.00,0.05$, $0.1,0.15$, and 0.175 ) were synthesized by sol-gel process. The prepared samples were sintered at 1100 and $1400{ }^{\circ} \mathrm{C}$ for $4 \mathrm{~h}$. The bulk densities were measured by Archimedes method. XRD measurements indicate that the synthesized samples were in single-phase cubic fluorite structure (space group $F m 3 m$ ). The cell parameters decrease with the concentration of $\mathrm{Mg}$, and $2 \theta$ values slightly shift towards right. The particle sizes obtained were between 7.14 and $17.44 \mathrm{~nm}$. The sintered sample achieved $95 \%$ of theoretical density. FTIR spectra of samples sintered at $1400{ }^{\circ} \mathrm{C}$ indicates weak interactions between $3550-3400 \mathrm{~cm}^{-1}$ and $1600-1300 \mathrm{~cm}^{-1}$ are attributed to $\mathrm{O}-\mathrm{H}$ stretching modes and strong bonds $850-450 \mathrm{~cm}^{-1}$ are assigned to characteristic $\mathrm{Ce}-\mathrm{O}$ vibrations. The surface morphology and chemical composition were analyzed by SEM and EDS, SEM micrographs show spherical faceted grains, and the samples were crack free, dense material with some pores on surface which are inconsistent with density results. The average grain size obtained was $0.5 \mu \mathrm{m}$. Particle size obtained by TEM was in agreement with that obtained by XRD. The high-density ceria co-doped ceramic can be used as electrolyte in SOFC.
\end{abstract}

Syed Ismail Ahmad

dr.syedismailahmad@gmail.com; sahmed@ibnsina.edu.sa

1 Physics Division, Department of Basic Sciences, Ibn Sina National College, P.O. Box No. 31096, Jeddah 21418, Kingdom of Saudi Arabia

2 Chemistry Division, Department of Basic Sciences, Ibn Sina National College, Jeddah, Kingdom of Saudi Arabia

3 International Advanced Research Centre for Powder Metallurgy and New Materials (ARCI), Hyderabad, TS, India
Keywords Sol-gel processes - Sintering · Scanning electron microscopy $(\mathrm{SEM}) \cdot \mathrm{CeO}_{2} \cdot$ Ceramic

\section{Introduction}

With fast depletion of fossil fuels, environmental concerns and growing demand for clean energy generation and storage around the world have led to the development of fuel cells. Solid oxide fuel cells (SOFCs) are the promising devices to produce clean energy being environmental friendly and are fuel flexible in nature. Among the three important parts of SOFCs cathode, anode, and electrolyte, the electrolyte plays an important role and it should be dense, high ionic conductivity and zero electronic conductivity, chemically stable at elevated temperature, gas tight/free of porosity, reduced (low) Ohmic losses, and thermal expansion which should match with electrodes (Minh and Takahashi 1995; Basu 2007). Nanostructured materials are widely used in many different applications in SOFCs because of their unique physical and chemical properties, different from bulk materials. The nanostructured solid-state ionic electrolyte termed "nanoionics" has become interest of research in advanced energy conversion and storage applications (Despotuli et al. 2005; Maier 2005; Despotuli and Andreeva 2010). The Yttria-stabilized Zirconia (YSZ) was used as electrolyte in solid oxide fuel cell (SOFC), and drawbacks such as high operating temperature in using YSZ as electrolyte can be eliminated by replacing it with cerium materials. Ceria is being used extensively because of its ability to store and release oxygen ion vacancies due to its easily accessible oxidation states from $\mathrm{Ce}^{3+} \rightleftarrows \mathrm{Ce}^{4+}$ and hence has high ionic conductivity due to oxygen vacancies (Zivkovic et al. 2011; Otake et al. 2003). 
Doped ceria is being preferred even over lanthanum gallate-based electrolyte because of its lower cost and it also lowers the operating temperature from 1000 to $600{ }^{\circ} \mathrm{C}$ which is also compatible with a wide range of electrodes and interconnects; furthermore, it enhances the life span of the fuel cell (Tarancón 2009; Rushton et al. 2013). Rareearth-doped ceria shows elevated ionic conductivity even at low temperatures below $773 \mathrm{~K}$, which turn them into potential electrolytes for intermediate temperature solid oxide fuel cells (IT-SOFC) (Inaba and Tagawa 1996; Yamashita 1995). Doping of $\mathrm{Ce}^{4+}$ with rare-earth elements such as $\mathrm{Sm}^{3+}, \mathrm{Gd}^{3+}, \mathrm{Nd}^{3+}$, etc leads to extra oxygen vacancies which increases ionic conductivity, lowers activation energy and increases stability from room temperature to its melting temperature. (Liu et al. 2008). The Krogner-Vink relation for oxygen vacancies can be written as $\mathrm{M}_{2} \mathrm{O}_{3} \stackrel{\mathrm{CeO}_{2}}{\longrightarrow} \mathrm{M}_{\mathrm{Ce}}^{\prime}+3 \mathrm{O}_{\mathrm{o}}^{X}+\mathrm{V}_{\mathrm{O}}^{\mathrm{oo}}$ where $\mathrm{M}$ is a trivalent rareearth metal. The dopants such as $\mathrm{Sm}^{3+}, \mathrm{Gd}^{3+}, \mathrm{Dy}^{3+}, \mathrm{Pr}^{3+}$, $\mathrm{Nd}^{3+}$, and $\mathrm{Y}^{3+}$ have higher solubility in ceria leading to elevated ionic conductivity. Among these rare-earth dopants, samarium is one of the best choice due to its ionic radius and electro negativity which are very close to that of ceria and hence easily soluble in ceria solid solution and can modify the structural and electrical properties (Wang et al. 2013). Different synthesis routes such as
Fig. 1 X-ray diffraction pattern of $\mathrm{Ce}_{0.8} \mathrm{Sm}_{0.2-y} \mathrm{Mg}_{y} \mathrm{O}_{2-\delta}$ $(y=0.00,0.05,0.1$, and 0.15$)$ was sintered at $1100{ }^{\circ} \mathrm{C}$

Fig. $2 \mathrm{X}$-ray diffraction pattern of $\mathrm{Ce}_{0.8} \mathrm{Sm}_{0.2-y} \mathrm{Mg}_{y} \mathrm{O}_{2-\delta}$ $(y=0.00,0.05,0.1,0.15$, and 0.175 ) was sintered at $1400{ }^{\circ} \mathrm{C}$
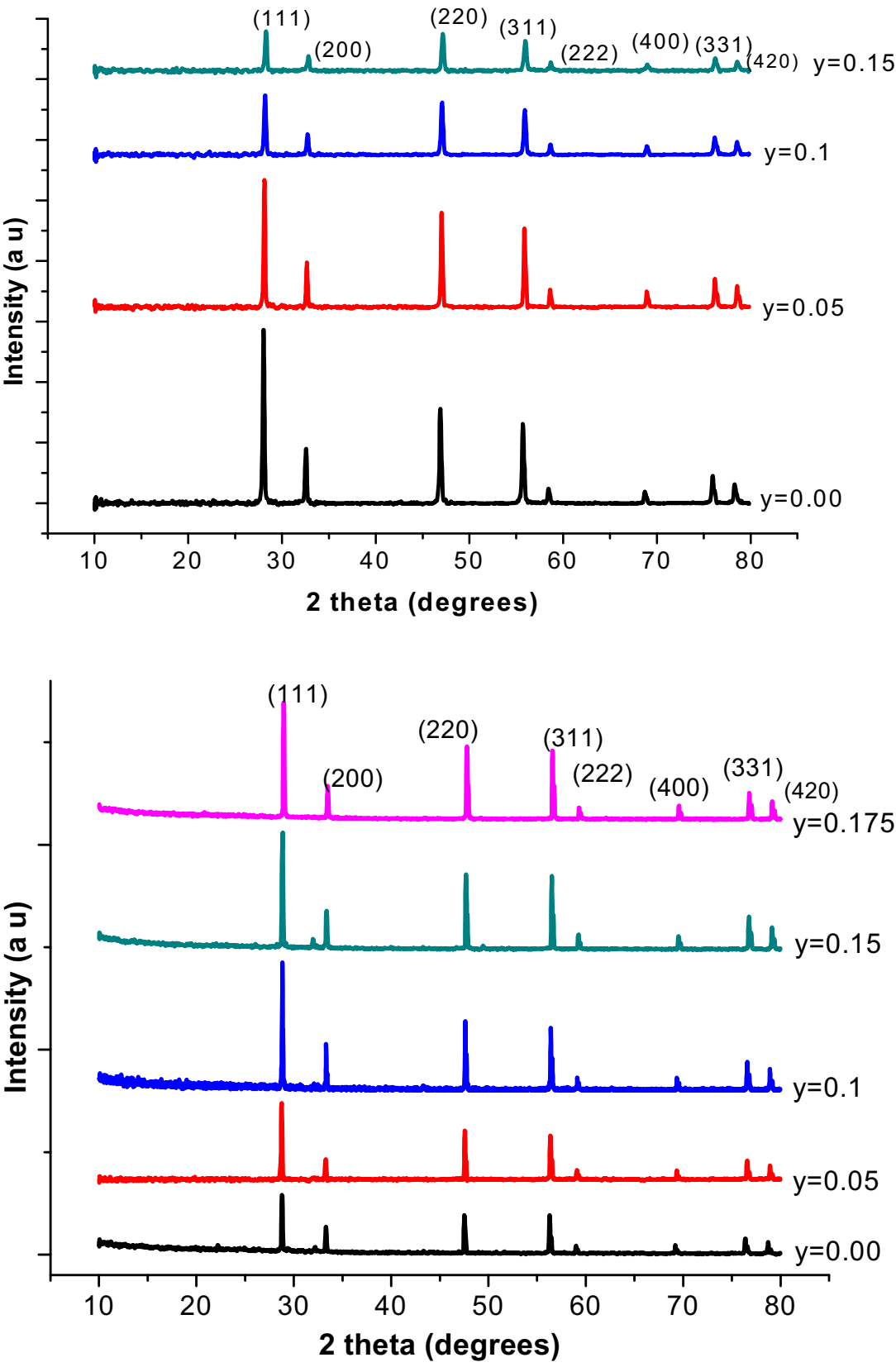
hydrothermal, co-precipitation, solid-state reaction, solvo thermal, and sol-gel auto combustion methods are being used to synthesize samarium-doped ceria (SDC) with different co-dopants to enhance the oxygen ion conductivity (Le et al. 2013; Wang et al. 2013). In the present work, ceria co-doped with $\mathrm{Sm}$ and $\mathrm{Mg}, \mathrm{Ce}_{0.8} \mathrm{Sm}_{0.2-y} \mathrm{Mg}_{y} \mathrm{O}_{2-\delta}$ $(y=0.00,0.05,0.1,0.15$, and 0.175$)$, has been synthesized by sol-gel process. The effect of sintering temperature on density and density, and effect of $\mathrm{Mg}$ substitution in Smdoped ceria on the properties, such as density, structural, and optical properties have been studied systematically.

\section{Experimental}

$\mathrm{Sm}$ and $\mathrm{Mg}$ co-doped ceria electrolytes of $\mathrm{Ce}_{0.8} \mathrm{Sm}_{0.2-y-}$ $\mathrm{Mg}_{y} \mathrm{O}_{2-\delta}(y=0.00,0.05,0.1,0.15$, and 0.175$)$ were synthesized by sol-gel auto combustion process. Analytical grades $\mathrm{Ce}\left(\mathrm{NO}_{3}\right)_{2} 6 \mathrm{H}_{2} \mathrm{O}, \mathrm{Sm}\left(\mathrm{NO}_{3}\right)_{3} 6 \mathrm{H}_{2} \mathrm{O}$, and $\mathrm{Mg}\left(\mathrm{NO}_{3}\right)_{3} 6$ $\mathrm{H}_{2} \mathrm{O}$ (99.99\% pure) were weighed in appropriate ratio, dissolved and mixed in $100 \mathrm{ml}$ de-ionized water in Pyrex beaker. Citric acid (reagent grade) was used as a chelating agent and ethylene glycol as a gel formation agent. Metal nitrate-to-citric acid ratio was kept at 1:3 to get a

Table 1 Lattice parameter $(a)$, X-ray density $\left(D_{\mathrm{x}}\right)$, bulk density $\left(D_{\mathrm{b}}\right), \%$ relative density $\left(D_{\mathrm{R}}\right)$, and crystallite size $(D) \mathrm{of} \mathrm{Ce}_{0.8} \mathrm{Sm}_{0.2-y} \mathrm{Mg}_{y} \mathrm{O}_{2-\delta}$ $(y=0.00,0.05,0.1$, and 0.15$)$ sintered at $1100{ }^{\circ} \mathrm{C}$

\begin{tabular}{llllllrr}
\hline S. no. & Sample code & Sample composition & $a(\AA)$ & $D_{\mathrm{x}}\left(\mathrm{g} / \mathrm{cm}^{3}\right)$ & $D_{\mathrm{b}}\left(\mathrm{g} / \mathrm{cm}^{3}\right)$ & $\% D_{\mathrm{R}}$ & $D(\mathrm{~nm})$ \\
\hline 1 & $20 \mathrm{SDC11}$ & $\mathrm{Ce}_{0.8} \mathrm{Sm}_{0.2} \mathrm{O}_{2-\delta}$ & 5.4304 & 7.1580 & $4.860 \pm 0.021$ & 68 & 7.15 \\
2 & $15 \mathrm{SMC11}$ & $\mathrm{Ce}_{0.8} \mathrm{Sm}_{0.15} \mathrm{Mg}_{0.05} \mathrm{O}_{2-\delta}$ & 5.4233 & 6.9218 & $4.983 \pm 0.032$ & 72 \\
3 & $10 \mathrm{SMC11}$ & $\mathrm{Ce}_{0.8} \mathrm{Sm}_{0.1} \mathrm{Mg}_{0.1} \mathrm{O}_{2-\delta}$ & 5.4195 & 6.6735 & $5.873 \pm 0.031$ & 88 & 17.51 \\
4 & $5 \mathrm{SMC11}$ & $\mathrm{Ce}_{0.8} \mathrm{Sm}_{0.05} \mathrm{Mg}_{0.15} \mathrm{O}_{2-\delta}$ & 5.419 & 6.4126 & $5.835 \pm 0.042$ & 91 & 17.51 \\
\hline
\end{tabular}

Table 2 Lattice parameter $(a)$, real dopants, X-ray density $\left(D_{\mathrm{x}}\right)$, bulk density $\left(D_{\mathrm{b}}\right), \%$ relative density $\left(D_{\mathrm{R}}\right)$, and crystallite size $(D)$ of Ce $\mathrm{e}_{0.8-}$ $\mathrm{Sm}_{0.2-y} \mathrm{Mg}_{y} \mathrm{O}_{2-\delta}\left(y=0.00,0.05,0.1,0.15\right.$, and 0.175) sintered at $1400{ }^{\circ} \mathrm{C}$

\begin{tabular}{|c|c|c|c|c|c|c|c|c|}
\hline \multirow[t]{2}{*}{ Sample code } & \multirow[t]{2}{*}{ Sample composition } & \multirow[t]{2}{*}{$a(\AA)$} & \multicolumn{2}{|c|}{ Real dopants } & \multirow[t]{2}{*}{$D_{\mathrm{x}}\left(\mathrm{g} / \mathrm{cm}^{3}\right)$} & \multirow[t]{2}{*}{$D_{\mathrm{b}}\left(\mathrm{g} / \mathrm{cm}^{3}\right)$} & \multirow[t]{2}{*}{$\% D_{\mathrm{R}}$} & \multirow[t]{2}{*}{$D(\mathrm{~nm})$} \\
\hline & & & $\mathrm{Sm}^{3+}$ & $\mathrm{Mg}^{2+}$ & & & & \\
\hline 20SDC14 & $\mathrm{Ce}_{0.8} \mathrm{Sm}_{0.2} \mathrm{O}_{2-\delta}$ & 5.4372 & 0.23 & 0.00 & 7.129 & $6.542 \pm 0.013$ & 90 & 7.14 \\
\hline 15SMC14 & $\mathrm{Ce}_{0.8} \mathrm{Sm}_{0.15} \mathrm{Mg}_{0.05} \mathrm{O}_{2-\delta}$ & 5.4367 & 0.163 & 0.043 & 6.873 & $6.392 \pm 0.033$ & 93 & 17.44 \\
\hline 10SMC14 & $\mathrm{Ce}_{0.8} \mathrm{Sm}_{0.1} \mathrm{Mg}_{0.1} \mathrm{O}_{2-\delta}$ & 5.4353 & 0.110 & 0.095 & 6.610 & $6.345 \pm 0.027$ & 96 & 17.43 \\
\hline 5SMC14 & $\mathrm{Ce}_{0.8} \mathrm{Sm}_{0.05} \mathrm{Mg}_{0.15} \mathrm{O}_{2-\delta}$ & 5.4340 & 0.054 & 0.146 & 6.359 & $6.105 \pm 0.033$ & 96 & 17.43 \\
\hline $2.5 \mathrm{SMC} 14$ & $\mathrm{Ce}_{0.8} \mathrm{Sm}_{0.025} \mathrm{Mg}_{0.175} \mathrm{O}_{2-\delta}$ & 5.4330 & 0.040 & 0.165 & 6.230 & $6.043 \pm 0.025$ & 97 & 17.43 \\
\hline
\end{tabular}

Fig. 3 Variation lattice parameter with $\mathrm{Mg}$ content in $\mathrm{Ce}_{0.8} \mathrm{Sm}_{0.2-y} \mathrm{Mg}_{y} \mathrm{O}_{2-\delta}$ sintered at 1400 and 1100

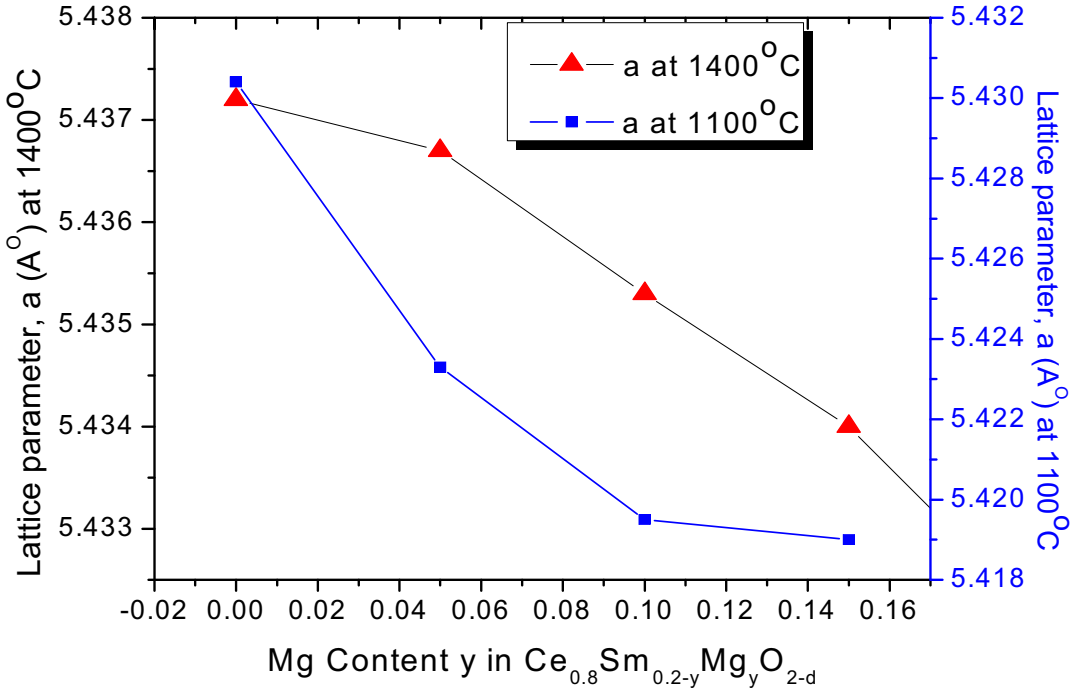


homogeneous and transparent solution, which was stirred by a magnetic stirrer at temperature $85^{\circ} \mathrm{C}$. The $\mathrm{pH}$ value was maintained at $7-8$ by adding ammonia solution dropwise. During continuous heating and stirring after $7-8 \mathrm{~h}$, the solution was dried and transformed into a viscous gel, and then, an auto combustion phenomenon occurred at around $350{ }^{\circ} \mathrm{C}$. The dried gel was converted into a lemon yellow fluffy powder which could be called precursor powder. The powder was then ground in agate motor and annealed at $500{ }^{\circ} \mathrm{C}$ for $4 \mathrm{~h}$ in furnace and cooled down to room temperature by shutting off the furnace. The powder again was ground and then pressed into disc-shaped pellets by adding PVA $(3-5 \%)$ as binder and was calcinated at $350{ }^{\circ} \mathrm{C}$ for $2 \mathrm{~h}$ for binder to decompose and evaporate.

The prepared pellets of samples of $\mathrm{Ce}_{0.8} \mathrm{Sm}_{0.2-y} \mathrm{Mg}_{y-}$ $\mathrm{O}_{2-\delta}(y=0.00,0.05,0.1$, and 0.15$)$ were sintered at $1100{ }^{\circ} \mathrm{C}$ for $4 \mathrm{~h}$ in the air and are identified as 20SDC11, 15SMC11, 10SMC11, and 5SMC11. The samples of
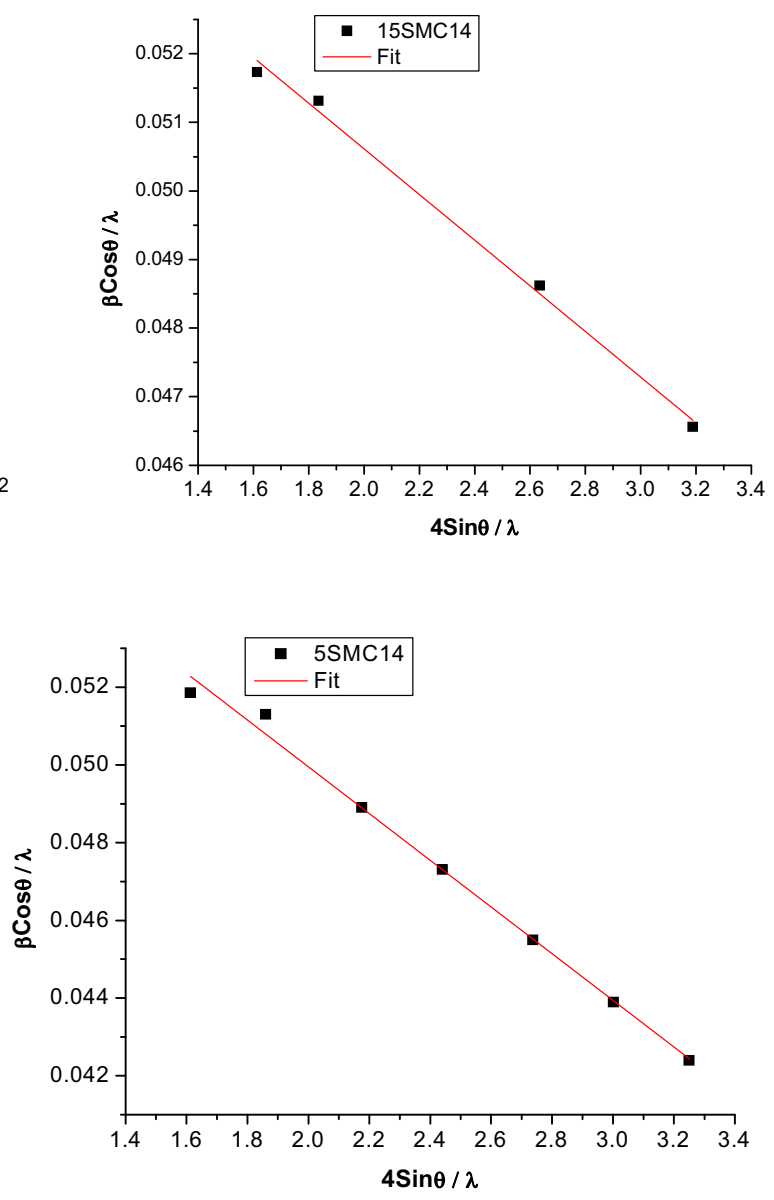

Fig. $4 \mathrm{~W}-\mathrm{H}$ plots for $\mathrm{Ce}_{0.8} \mathrm{Sm}_{0.2-y} \mathrm{Mg}_{y} \mathrm{O}_{2-\delta}(y=0.00,0.05,0.1$, and 0.15$)$ sintered at $1400{ }^{\circ} \mathrm{C}$

Table 3 Dislocation density $(\delta)$, lattice strain $(\varepsilon)$, and Crystallite size (D) of $\mathrm{Ce}_{0.8} \mathrm{Sm}_{0.2-\mathrm{y}} \mathrm{Mg}_{\mathrm{y}} \mathrm{O}_{2-\delta}(y=0.00,0.05,0.1$, and 0.175$)$ sintered at $1400{ }^{\circ} \mathrm{C}$

\begin{tabular}{lllllllc}
\hline Sample code & Intercept & $\begin{array}{l}\mathrm{D}(\mathrm{nm}) \\
(1 / \text { intercept })\end{array}$ & $\begin{array}{l}\text { Slope } \\
\text { (lattice strain) }\end{array}$ & $\mathrm{R}^{2}$ & $\begin{array}{l}\text { Effective } \\
\varepsilon=\beta / 4 \tan \theta\left(10^{-3}\right)\end{array}$ & $\begin{array}{l}\text { Dislocation density } \\
\delta\left(\times 10^{15} \operatorname{lines} / \mathrm{m}^{2}\right)\end{array}$ & $\begin{array}{l}\text { Effective } \\
\delta\left(\times 10^{15} l i n e s / \mathrm{m}^{2}\right)\end{array}$ \\
\hline 20SDC14 & 0.181 & 5.52 & -0.03 & 0.920 & 21.86 & 19.61 & 32.8 \\
15SMC14 & 0.0571 & 17.49 & -0.0032 & 0.99 & 9.09 & 3.303 & 3.26 \\
10SMC14 & 0.0579 & 17.27 & -0.0036 & 0.97 & 8.9 & 3.29 & 3.35 \\
5SMC14 & 0.0619 & 16.15 & -0.006 & 0.98 & 8.96 & 3.3 & 3.83 \\
2.5SMC14 & 0.05705 & 17.52 & -0.0031 & 0.98 & 8.94 & 3.29 & 3.25 \\
\hline
\end{tabular}


$\mathrm{Ce}_{0.8} \mathrm{Sm}_{0.2-y} \mathrm{Mg}_{y} \mathrm{O}_{2-\delta} \quad(y=0.00, \quad 0.05, \quad 0.1, \quad 0.15$, and 0.175 ) were sintered at $1400{ }^{\circ} \mathrm{C}$ for $4 \mathrm{~h}$ in the air and are identified as 20SDC14, 15SMC14, 10SMC14, 5SMC14, and 2.5SMC14, respectively. X-ray diffraction (XRD) of the pellet was performed by Shimadzu XRD 700 X-ray diffractometer using $\mathrm{Cu} \mathrm{K} \alpha$ radiation $(\lambda=1.54 \AA$ ). XRD data further used to confirm the phase and structural properties such as theoretical density and dislocation density. The surface morphology was studied using scanning electron microscope (Zeiss Evo series SEM) at operating voltage of $15 \mathrm{kV}$. Grain sizes were measured by higher magnification SEM micrographs. The elemental analysis was carried out by EDAX to confirm the chemical composition of samples. IR spectra were recorded using Shimadzu FTIR 8400 spectrometer over a wave number range $400-4000 \mathrm{~cm}^{-1}$ to find functional groups present. TEM technique is employed to confirm the particle size as obtained by XRD.

\section{Results and discussions}

\section{X-ray diffraction analysis}

The phase purity of the samples was examined by X-ray diffraction (XRD). The XRD pattern of $\mathrm{Ce}_{0.8} \mathrm{Sm}_{0.2-y} \mathrm{Mg}_{y-}$ $\mathrm{O}_{2-\delta}(y=0.00,0.05,0.1,0.15$, and 0.175$)$ sintered at 1100 and $1400{ }^{\circ} \mathrm{C}$ is shown in Figs. 1 and 2. It is observed that the samples reveal single-phase fluorite structure without any ambiguous reflections. The diffraction peaks corresponding to planes (111), (200), (220), (311), (222), (400), (311), and (420) provide a clear evidence for the formation of single-phase cubic fluorite structure (space group Fm3 m) of $\mathrm{CeO}_{2}$ JCPDS Card No. 34-0394 (Inaba Hand Tagawa 1996; Bhabu et al. 2015). Furthermore, XRD pattern indicates that the synthesized powder contains nanosize crystallites. Scherrer's formula is employed to calculate the crystallite size:

$D=\frac{k \lambda}{\beta \operatorname{Cos} \theta}$

where $k=0.91, \lambda$ is wavelength of $\mathrm{X}$-rays $(\lambda=1.54 \AA), \beta$ is FWHM in radians, and $\theta$ is the angle of diffraction. The average crystallite size was found in case of 20SDC14 was $7.14 \mathrm{~nm}$, while that for $\mathrm{Mg}$ substituted SDC was in the range $17 \mathrm{~nm}$. The lattice parameter was found using

$a=d \sqrt{h^{2}+k^{2}+l^{2}}$

where $d$ is inter-planar distance of a plane of Miller indices (hkl). Tables 1, 2 show various parameters of the sample sintered at 1100 and $1400{ }^{\circ} \mathrm{C}$. It is evident from Fig. 2 that the $\mathrm{Mg}$ substitution in SDC led to shift in the peaks to higher angles, indicating that the lattice parameters are decreased. The shift in the peaks is due to difference in ionic radii of dopants leading to strain in the crystal. Since $\mathrm{Mg}^{2+}(0.72 \AA)<\mathrm{Ce}^{4+}(0.97 \AA)<\mathrm{Sm}^{3+}(1.08 \AA)$, the peak shifts towards right (Ahmad et al. 2016). The variation of lattice parameters with $\mathrm{Mg}$ concentration for samples sintered at 1100 and $1400{ }^{\circ} \mathrm{C}$ is shown in Fig. 3 .

The lattice strain produced in the crystal can be found by $\varepsilon=\frac{\beta}{4 \tan \theta}$ and the corresponding dislocation density is given by $\delta=1 / D^{2}$, where $D$ is crystallite size determined by Scherrer's formula and $\beta$ is FWHM. Williamson-Hall equation $\frac{\beta \cos \theta}{\lambda}=\frac{k}{D}+\frac{4 \varepsilon \sin \theta}{\lambda}$ was also employed to find the effective lattice strain $(\varepsilon)$, effective crystallite size $(D)$, and dislocation density $(\delta)$ considering lattice strain (Choudhury and Choudhry 2013; Parchur et al. 2014). Figure 4 depicts Williamson-Hall plots (W-H plots) for samples sintered at $1400{ }^{\circ} \mathrm{C}$, and the parameters obtained are tabulated in Table 3. It is observed that the crystallite size $(D)$ obtained by Scherrer's formula is in good agreement with that obtained by inverse of slope of $\mathrm{W}-\mathrm{H}$ plots; furthermore, both dislocation density $(\delta)$ and lattice strain $(\varepsilon)$ are affected by magnesium concentration in SDC crystal [Yadav et al. 2016]. The substitution of Sm and Mg in ceria creates oxygen vacancies $\left(V_{o}^{\bullet \bullet}\right)$, and the Kroger-Vink notation can be written as (Bhabu et al. 2015; Parchur et al. 2014)

$\mathrm{Sm}_{2} \mathrm{O}_{3} \stackrel{2 \mathrm{CeO} 2}{\longrightarrow} 2 \mathrm{Sm}_{\mathrm{Ce}}^{\prime}+3 \mathrm{O}_{o}^{\times}+\mathrm{V}_{o}^{\bullet \bullet}$

$\mathrm{MgO} \stackrel{\mathrm{CeO}_{2}}{\longrightarrow} \mathrm{Mg}_{\mathrm{Ce}}^{\prime \prime}+\mathrm{O}_{o}^{\times}+\mathrm{V}_{o}^{\bullet \bullet}$, one oxygen vacancy would be created for each $2 \mathrm{Sm}$ atoms and one $\mathrm{Mg}$ atom introduced in ceria. As $\mathrm{Mg}$ concentration is increased, more oxygen vacancies $\left(V_{o}^{\bullet \bullet}\right)$ are produced, and a decrease in the lattice parameter is expected due to difference in their ionic radii which affects the lattice strain and dislocation density (Zheng et al. 2009).

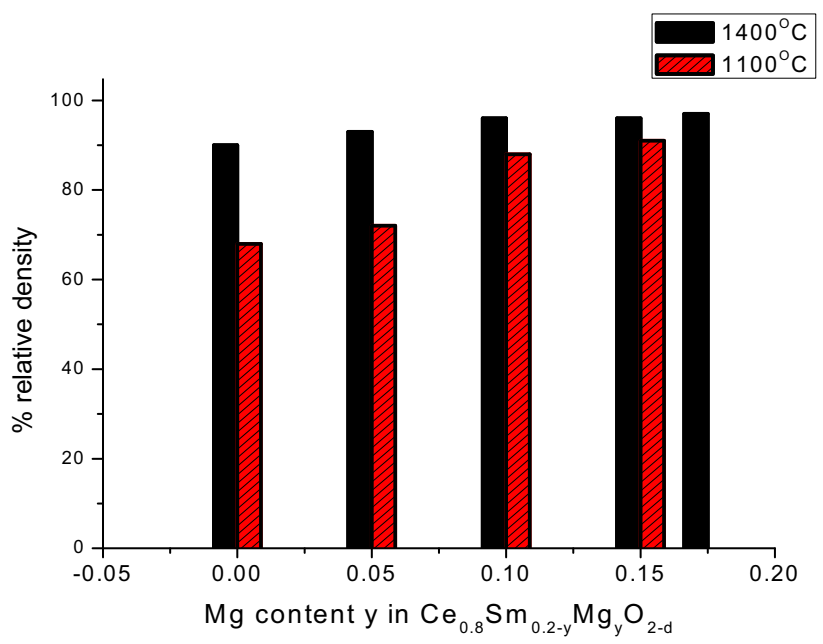

Fig. 5 Variation of relative density with $\mathrm{Mg}$ content in $\mathrm{Ce}_{0.8} \mathrm{Sm}_{0.2-y-}$ $\mathrm{Mg}_{y} \mathrm{O}_{2-\delta}$ sintered at 1400 and $1100{ }^{\circ} \mathrm{C}$ 


\section{Density}

The bulk density $\left(D_{\mathrm{b}}\right)$ of the samples was measured by Archimedes' method. The X-ray density $\left(D_{\mathrm{X}}\right)$ of the samples is calculated using

$D_{X}=\frac{4}{N_{A} a^{3}}\left[0.8 \mathrm{M}_{\mathrm{Ce}}+(0.2-x) \mathrm{M}_{\mathrm{Sm}}+x \mathrm{M}_{\mathrm{Mg}}+1.9 M_{O}\right]$

where $N_{\mathrm{A}}$ is Avogadro's number, 'a' is lattice constant, and $\mathrm{M}_{\mathrm{Ce}}, \mathrm{M}_{\mathrm{Sm}}, \mathrm{M}_{\mathrm{Mg}}$, and $\mathrm{M}_{\mathrm{O}}$ are atomic weights of $\mathrm{Ce}, \mathrm{Sm}$, $\mathrm{Mg}$, and oxygen, respectively (Ahmad et al. 2017). The \% $D_{\mathrm{R}}$ was calculated by $\% D_{\mathrm{R}}=\left(D_{\mathrm{b}} / D_{\mathrm{x}}\right) \times 100$. Figure 5 shows the relative density of samples sintered at 1100 and $1400{ }^{\circ} \mathrm{C}$ temperature vs $\mathrm{Mg}$ content. The relative density of 20SDC samples increased from 68 to $82 \%$ due to an increase in temperature from 1100 to $1400{ }^{\circ} \mathrm{C}$. Furthermore, it is observed that substitution of $\mathrm{Mg}$ in SDC increases the relative density. The relative density of 5SMC11 is comparable with that of 20SDC14, which shows that the alkali earth metals can be used as sintering aid in ceria ceramics (Zheng et al. 2011). The cross-sectional micrograph of 20SDC14 pellet in Fig. 6 shows some closed pores indicating not-fully dense microstructure which affects the ionic conductivity of electrolyte.

The decrease in X-ray density due to lattice contraction has led to decrease in strain and dislocation density (Najafi and Eshghi 2015). However, at higher concentration of $\mathrm{Mg}$ in SDC, the relative density is almost constant. It could be concluded that a dense ceramic electrolyte optimum level of doping with rare-earth metals and sintering temperature are equally required. The sintering temperature has affected the lattice parameter and relative density and least effect on crystallite size.

\section{SEM and EDAX analysis}

The SEM micrographs of synthesized samples of ceria codoped with $\mathrm{Sm}$ and $\mathrm{Mg}$ sintered at $1400{ }^{\circ} \mathrm{C}$ with a dwell time of $4 \mathrm{~h}$ are shown in Fig. 6. All the samples show corncomb structure suggesting that they are fully dense with more than $90 \%$ of theoretical density $D_{\mathrm{x}}$, with relatively

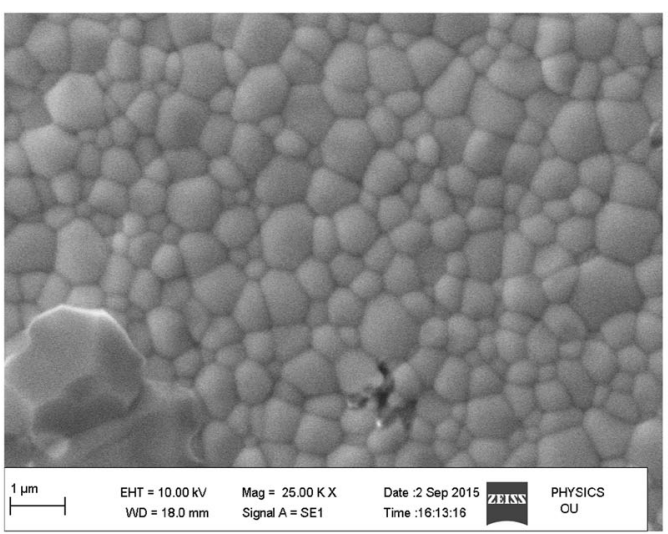

10SMC $14\left(\mathrm{Ce}_{0.8} \mathrm{Sm}_{0.1} \mathrm{Mg}_{0.1} \mathrm{O}_{2-\delta}\right)$

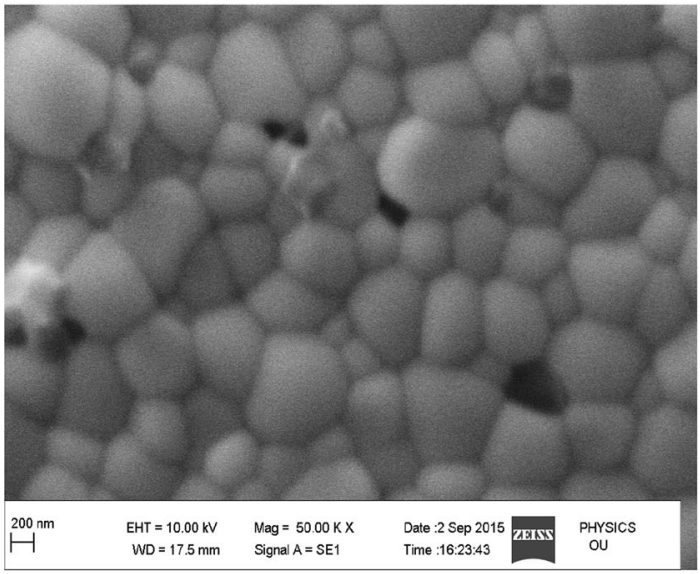

20SDC $14\left(\mathrm{Ce}_{0.8} \mathrm{Sm}_{0.2} \mathrm{O}_{2-\delta}\right)$

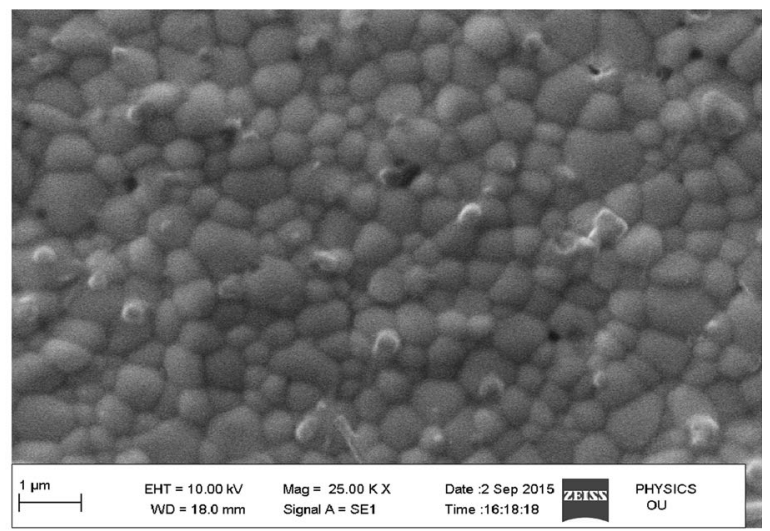

$15 \mathrm{SMC} 14\left(\mathrm{Ce}_{0.8} \mathrm{Sm}_{0.15}\right)$

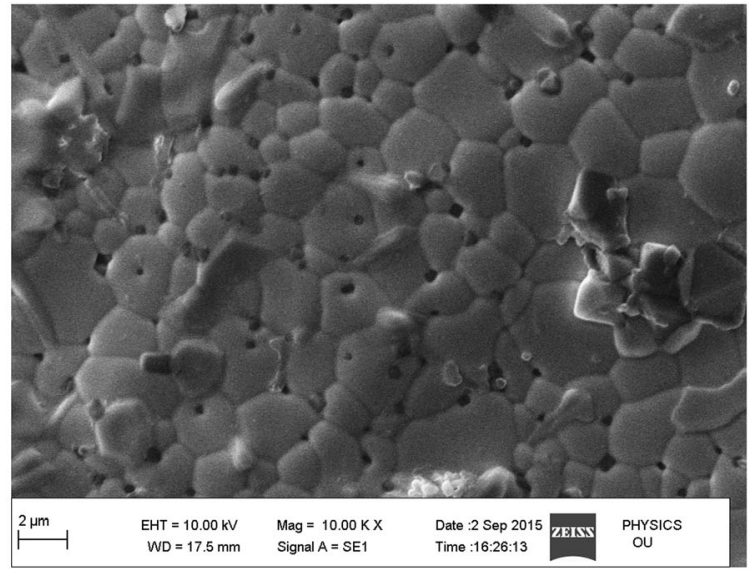

Cross-sectional fracture surface of 20SDC 14

Fig. 6 SEM micrographs of $\mathrm{Ce}_{0.8} \mathrm{Sm}_{0.2-y} \mathrm{Mg}_{y} \mathrm{O}_{2-\delta}$ sintered at $1400{ }^{\circ} \mathrm{C}$ 
Fig. 7 EDAX spectra of

$\mathrm{Ce}_{0.8} \mathrm{Sm}_{0.2-y} \mathrm{Mg}_{y} \mathrm{O}_{2-\delta}$

$(y=0.00,0.05,0.1$, and 0.15$)$

sintered at $1400{ }^{\circ} \mathrm{C}$

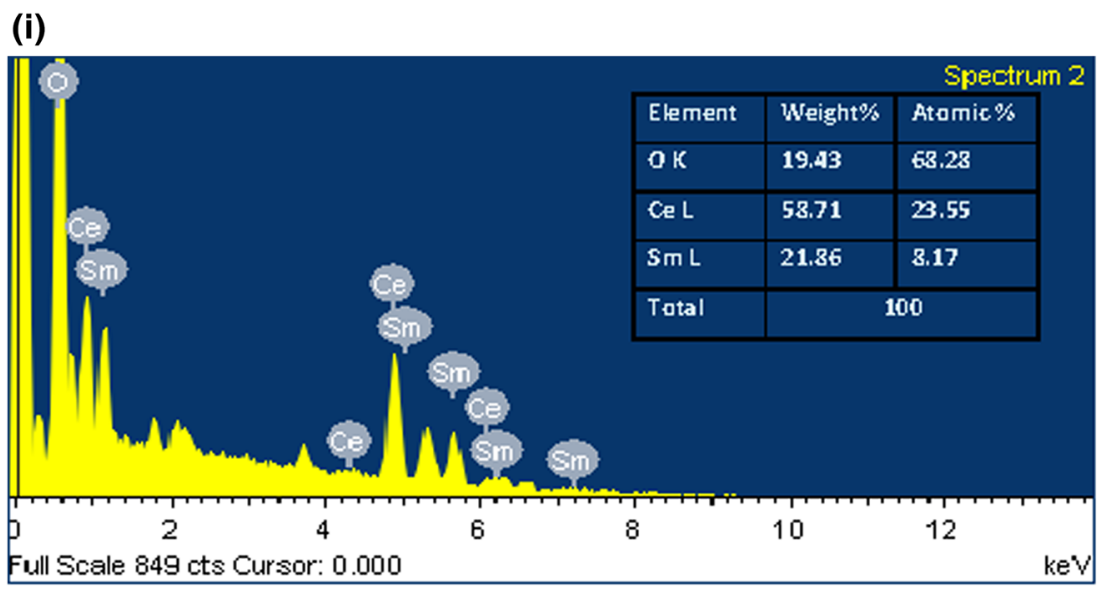

(ii)

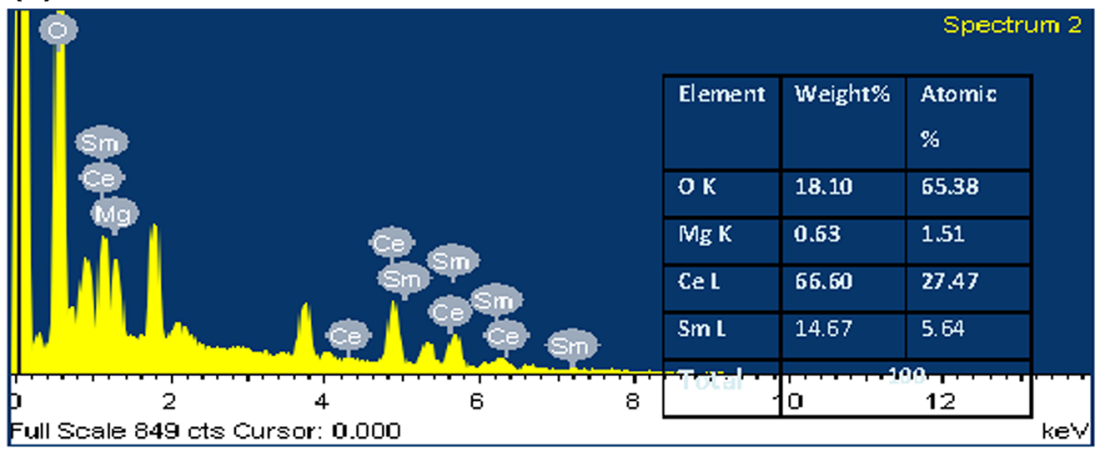

(iii)

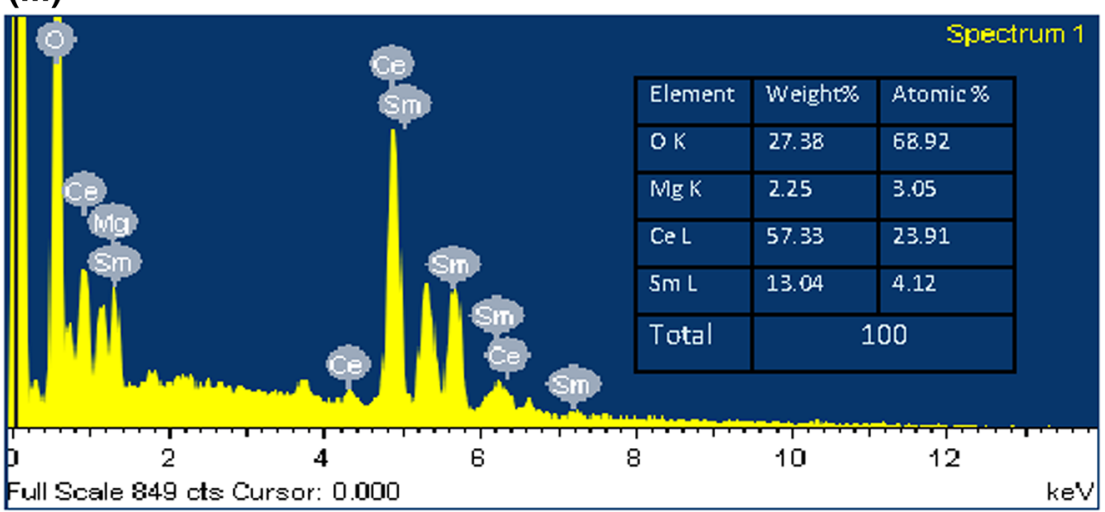

(iv)

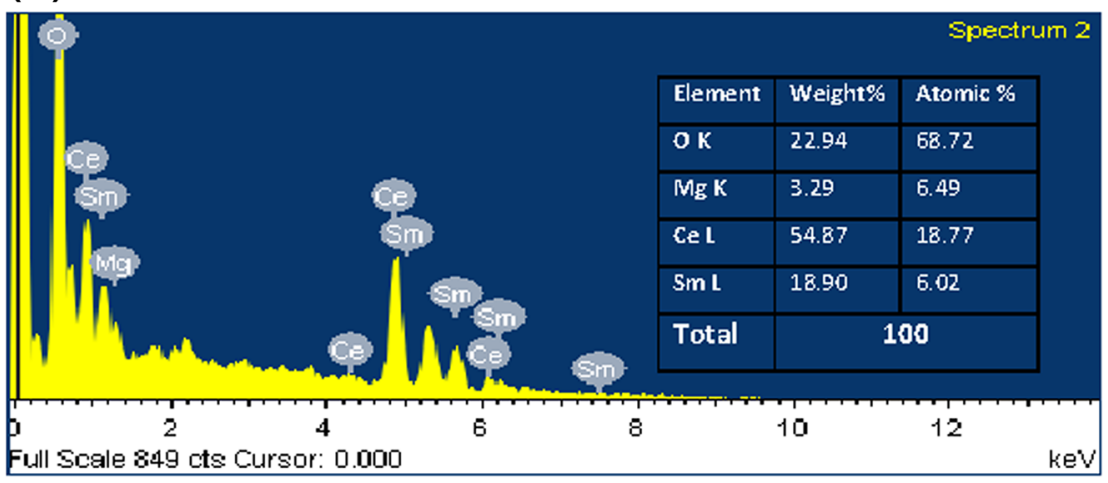



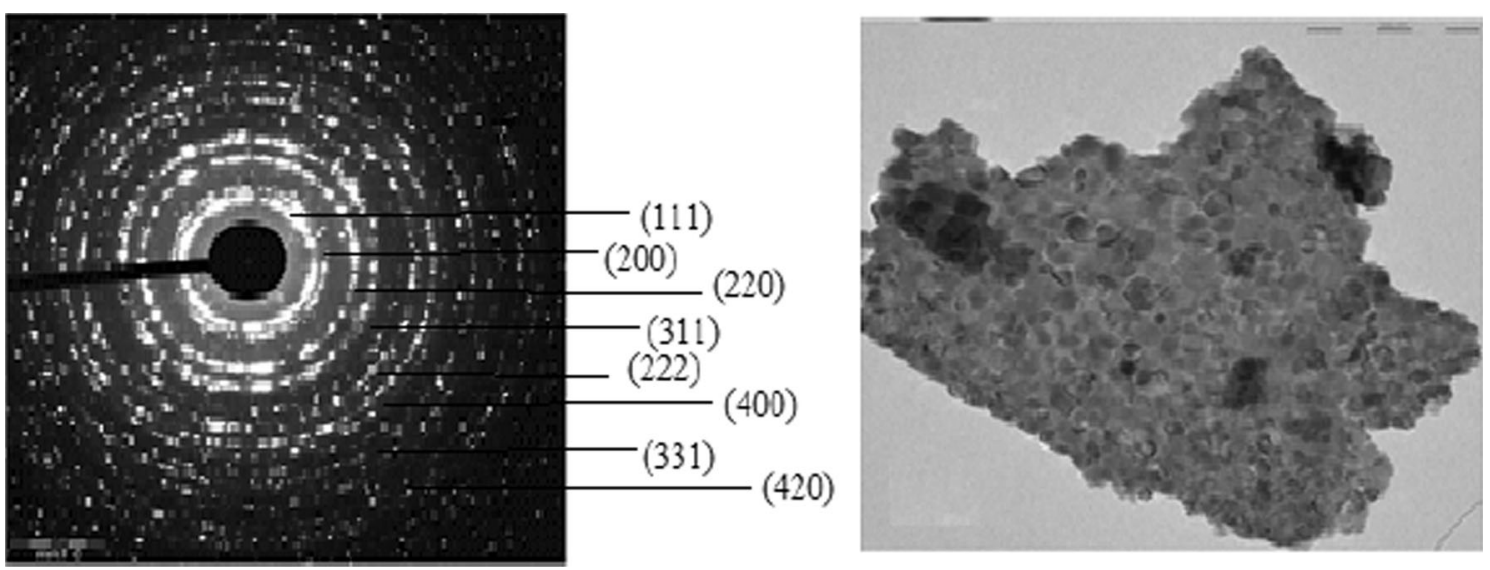

Fig. 8 TEM micrograph of 20SDC14

Fig. 9 FTIR spectra of $\mathrm{Ce}_{0.8} \mathrm{Sm}_{0.2-y} \mathrm{Mg}_{y} \mathrm{O}_{2-\delta}$ sintered at $1100{ }^{\circ} \mathrm{C}$

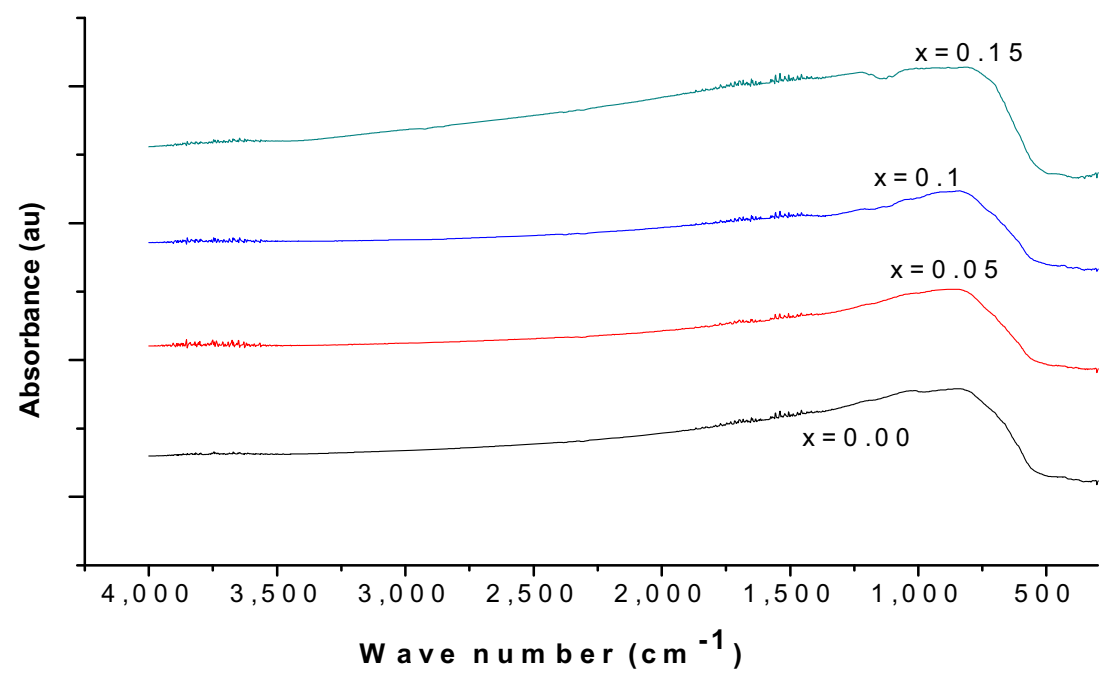

smaller volume of grain boundary [Ramesh et al. 2011]. No significant effect of $\mathrm{Mg}$ substitution on the microstructure and no exaggerated grain growth were observed. The grain size was measured using Line-Intercept method using formula $\bar{G}=\frac{1.570}{N_{L}}$, where $N_{L}=\frac{\text { No.ofgrains }}{\text { Length of the test line }}$. The average grain size was found to be $0.5 \mu \mathrm{m}$ (Donmez et al. 2015). The spherically shaped smaller particle size sample is very much desired to obtain dense ceramics. The semi-quantitative information about the sample's chemical composition can be obtained by EDAX spectra. The EDAX spectra of the samples are shown in Fig. 7 which confirms the desired stoichiometry of all the constituent elements in the sample. The calculated real-dopant concentration is tabulated in Table 1.

\section{TEM analysis}

Figure 8 shows TEM micrograph and SAED pattern of synthesized samarium-doped ceria sintered at $1400{ }^{\circ} \mathrm{C}$. The particle size measured from TEM is $9 \mathrm{~nm}$ which is in agreement with that obtained from XRD (Prado-Gonjal et al. 2012).

\section{FT-IR analysis}

$\mathrm{KBr}$ pellet method has been used to record the IR spectra to get an insight into the reaction of sol-gel formation of solid solution of $\mathrm{Ce}_{0.8} \mathrm{Sm}_{0.2-} \mathrm{Mg}_{y} \mathrm{O}_{2-\delta}$ sintered at $1100{ }^{\circ} \mathrm{C}$. The FT-IR spectra recorded is shown in Fig. 9. The weak intensities occurring in the range 3550-3400 and 1600-1300 $\mathrm{cm}^{-1}$ can be assigned to $\mathrm{O}-\mathrm{H}$ stretching vibrations of hydroxyl group, probably due to moisture content of $\mathrm{KBr}$, as $\mathrm{KBr}$ is hydroscopic absorbs more humidity in the atmosphere. The strong bands at around $850-450 \mathrm{~cm}^{-1}$ can be attributed to characteristic $\mathrm{Ce}-\mathrm{O}$ vibrations (Shehata et al. 2012; Ainirad et al. 2011; Arabaci and Oksuzomer 2012). The intensities of all other bands at $3550-3400$ and $1600-1300 \mathrm{~cm}^{-1}$ have been reduced significantly because of high sintering temperature of $1100{ }^{\circ} \mathrm{C}$ due to which the adsorbed water has been removed and improving the crystallinity of the samples. 


\section{Conclusions}

Nanocrystalline $\mathrm{Sm}$ and $\mathrm{Mg}$ co-doped ceria with formula $\mathrm{Ce}_{0.8} \mathrm{Sm}_{0.2-y} \mathrm{Mg}_{y} \mathrm{O}_{2-\delta}(y=0.00,0.05,0.1$, and 0.175$)$ successfully synthesized by auto combustion sol-gel process. The pellets were prepared and sintered at 1100 and $1400{ }^{\circ} \mathrm{C}$. XRD pattern confirms the cubic fluorite structure, the substitution of $\mathrm{Mg}$ in SDC led to decrease in lattice parameter and crystallite size of all compositions which was confirmed by Williamson-Hall plots, and oxygen vacancies produced affects the dislocation density. SEM micrographs show corncomb structure with an average grain size of $0.5 \mu \mathrm{m}$. Optimum level of doping with alkali earth metals and sintering temperature are equally required for dense ceramic electrolyte, and sintering temperature affects the lattice parameter and relative density and shows least effect on crystallite size.

Open Access This article is distributed under the terms of the Creative Commons Attribution 4.0 International License (http:// creativecommons.org/licenses/by/4.0/), which permits unrestricted use, distribution, and reproduction in any medium, provided you give appropriate credit to the original author(s) and the source, provide a link to the Creative Commons license, and indicate if changes were made.

\section{References}

Ahmad SI, Kumar DR, Syed IA, Satar R, Ansari SA (2017) Structural, spectroscopic and magnetic study of nanocrystalline cerium-substituted magnesium ferrites. Arab J Sci Eng 42:389. doi:10.1007/s13369-016-2297-x

AhmadS I, Rao PK, Syed IA (2016) Sintering temperature effect on density, structural and morphological properties of $\mathrm{Mg}$ - and $\mathrm{Sr}$ doped ceria. J Taibah Univ Sci 10:381-385. doi:10.1016/j.jtusci. 2015.04.003

Ainirad A, Motlagh MMK, Maghsoudipoor A (2011) A systematic study on the synthesis of $\mathrm{Ca}, \mathrm{Gd}$ codoped cerium oxide by combustion method. J Alloys Compd 509(5):1505-1510. doi:10. 1016/j.jallcom.2010.10.137

Arabaci A, Oksuzomer MF (2012) Preperation and characterization of $10 \mathrm{~mol} \%$ Gd doped $\mathrm{CeO}_{2}$ (GDC) electrolyte for SOFC applications. Ceramic Internal 38:6509-6515. doi:10.1016/j.ceramint. 2012.05.030

Basu S (2007) Recent trends in fuel cell science and technology. Springer and Anamaya Publishers, New Delhi

Bhabu AK, Theerthagiri J, Madhavan J, Balu T, Muralidharan G, Rajasekaran TR (2015) Cubic fluorite phase of samarium doped cerium oxide $\left(\mathrm{CeO}_{2}\right) 0.96 \mathrm{Sm} 0.04$ for solid oxide fuel cell electrolyte. J Mater Sci Mater Electron 27:1566-1573. doi:10. 1007/s10854-015-3925-z

Choudhury B, Choudhry A (2013) Local structure modification and phase transformation of $\mathrm{TiO}_{2}$ nanoparticles initiated by oxygen defects, grain size, and annealing temperature. Int Nano Lett. doi: 10.1186/2228-5326-3-55

Despotuli AL, Andreeva AV (2010) Nanoionics: new materials and supercapacitors. Nanotechnol Russ 5:506-520. doi:10.1134/ S1995078010070116

Despotuli AL, Andreeva AV, Rambabu B (2005) Nanoionics of advanced superionic conductors. Ionics 11:306-314. doi:10. 1007/BF02430394
Donmez G, Sarıboga V, Altıncekic TG, Oksuzomer MAF (2015) Polyol synthesis and investigation of $\mathrm{Ce}_{1-\mathrm{x}} \mathrm{RE}_{\mathrm{x}} \mathrm{O}_{2-\mathrm{x} / 2}(\mathrm{RE}=\mathrm{Sm}$, $\mathrm{Gd}, \mathrm{Nd}$, La, $0 \leq x \leq 0.25$ ) electrolytes for IT-SOFCs. J Am Ceram Soc 98(2):501-509. doi:10.1111/jace.13300

Inaba H, Tagawa H (1996) Ceria-based solid electrolytes: review. Solid State Ionics 83:1-16. doi:10.1016/0167-2738(95) 00229-4

Le S, Zhu S, Zhu X, Sun K (2013) Densification of $\mathrm{Sm}_{0.2} \mathrm{Ce}_{0.8} \mathrm{O}_{1.9}$ with the addition of lithium oxide as sintering aid. J Power Sources 222:367-372. doi:10.1016/j.jpowsour.2012.08.020

Liu Y, Liu B, Wei X, Pan W (2008) Citrate nitrate combustion synthesis and electrical conductivity of $\mathrm{Sm}^{3+}, \mathrm{Nd}^{3+}$ Co-doped ceria electrolyte. J Am Ceram Soc 91(12):3926-3930

Maier J (2005) Nanoionics: ion transport and electrochemical storage in confined systems. Nat Mater 4:806-815. doi:10.1038/ nmat 1513

Minh N Q, Takahashi T (1995) Science and technology of ceramic fuel cells. Elsevier. ISBN 978-0-444-89568-4

Najafi M, Eshghi H (2015) The effect of Cu-doping on physical properties of nanostructured $\mathrm{NiO}$ thin films prepared by spray pyrolysis technique. Scientia Iranica F 22(3):1317-1321

Otake T, Yugamib H, Yashiroa K, Nigaraa Y, Kawada T, Mizusaki J (2003) Nonstoichiometry of $\mathrm{Ce}_{1-x} \mathrm{Y}_{x} \mathrm{O}_{2-0.5 x-\delta}(x=0.1,0.2)$. Solid State Ionics 161:181-186. doi:10.1016/S0167-2738(02) 00873-1

Parchur AK, Ansari AA, Singh BP, Hasan TN, Syed NA, Rai SB, Ningthoujam RS (2014) Enhanced luminescence of CaMoO4: Eu by core@shell formation and its hyperthermia study after hybrid formation with $\mathrm{Fe} 3 \mathrm{O} 4$ : cytotoxicity assessment on human liver cancer cells and mesenchymal stem cells. Integr Biol 6(1):53-64. doi:10.1039/c3ib40148k

Prado-Gonjal J, Schmidt R, Espíndola-Canuto J, Ramos-Alvarez P, Morán E (2012) Increased ionic conductivity in microwave hydrothermally synthesized rare-earth doped ceria $\mathrm{Ce}_{1-\mathrm{x}} \mathrm{RE}_{\mathrm{x}-}$ $\mathrm{O}_{2-(x / 2)}$. J Power Sour 209:163-171. doi:10.1016/j.jpowsour. 2012.02.082

Ramesh S, James Raju KC, Reddy CV (2011) Synthesis and Characterization of Co-Doped Ceria Ceramics by Sol-Gel Method. Trans Ind Ceram Soc 70(3):143-147. doi:10.1080/ 0371750X.2011.10600161

Rushton MJD, Chroneos A, Skinner SJ, Kilner JA, Grimes RW (2013) Effect of strain on the oxygen diffusion in yttria and gadolinia co-doped ceria. Solid State Ionics 230:37-42. doi:10. 1016/j.ssi.2012.09.015

Shehata N, Meehan K, Hudait M, Jain N (2012) Control of oxygen vacancies and $\mathrm{Ce}^{+3}$ concentrations in doped ceria nanoparticles via the selection of lanthanide element. J Nano Part Res 14 (11):1173. doi:10.1007/s11051-012-1173-1

Tarancón A (2009) Strategies for lowering solid oxide fuel cells operating temperature. Energies 2(4):1130-1150. doi:10.3390/ en20401130

Wang SF, Yeh CT, Wang YR, Yu-Chuan W (2013) Characterization of samarium-doped ceria powders prepared by hydrothermal synthesis for use in solid state oxide fuel cells. J Mater Res Technol 2:141-148. doi:10.1016/j.jmrt.2013.01.004

Yadav A, Rajpoot R, Dar M A, Varshney D (2016) Investigations on structural, vibrational and dielectric properties of nanosized $\mathrm{Cu}$ doped $\mathrm{Mg}-\mathrm{Zn}$ ferrites. Citation: AIP Conference Proceedings 1731, 050008 (2016). doi:10.1063/1.4947662

Yamashita K (1995) Hydrothermal synthesis and low temperature conduction properties of substituted ceria ceramic. Solid State Ionics 81:53-60. doi:10.1016/0167-2738(95)99031-H

Zheng Y, Gu H, Gao L, Zhu X, Guo L (2009) Effect of Sm and Mg co-doping on the properties of ceria-based electrolyte material for IT-SOFCs. Mater Res Bull 44:775-779. doi:10.1016/j. materresbull.2008.09.021

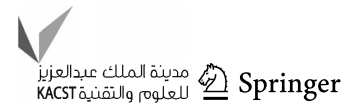


Zheng Y, He S, Ge L, Zhou M, Chen H, Guo L (2011) Effect of Sr on Sm-doped ceria electrolyte. Intl J Hydrogen Energy 36(8):5128-5135. doi:10.1016/j.ijhydene.2011.01.042
Zivkovic LS, Lair V, Lupan O, Cassir M, Ringuede A (2011) Samarium doped Ceria nano structured thin films grown on FTO glass by Electrodeposition. Acta Phys Pol A 120(2):298-302 